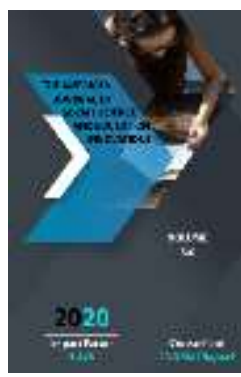

\title{
Research Of The Epic “Amir Temur And Boyazid”
}

\author{
Abduolim Ergashev \\ Associate Professor, Karshi State University, Uzbekistan
}

Journal Website: http://usajournalshub.c om/index,php/tajssei

\section{ABSTRACT}

The article is devoted to the creation of typical characters and conditions of historical realities and personalities in the epic, genre features and themes of the historical epic, the depiction of historical folk fiction in the epic in the shell of epic poetics, the artistic generalization of the historical period and image, the creation of a historical epic in the Kashkadarya-Surkhandarya epic features, including the role of the school of epic poetry and pedagogical traditions, the interpretation of images in the epic "Amir Temur and Boyazid", his role in the all-Uzbek epic and ideological and artistic features.

\section{KEYWORDS}

Historiography, historical epic, epic, image, plot, genre, artistic-visual medium, bakhshi, school of epic, epic repertoire.

\section{INTRODUCTION}

Historical epics constitute a special type of epic, the ideological basis of which is the artistic expression of the epic image of a historical event and historical figures. The problem of historicity is one of the important factors in the folklore of all peoples. For works of folklore, historicity is one of the historically formed and changing features of the artistic reflection of the history of the people. The question of historicality and historical reality is evaluated in folklore works in terms of the principles of generality and specificity. Because 
in each performed, created folklore works important events in the socio-economic and everyday life of the people are the essence of the historical period, as well as the artistic reflection of the image of historical figures at the turning points in the fate of the people of that period. For this reason, the historical generalization that is part of any genre affects the artistic means and methods of the genre in the description of events. There are also works in historical genres that depict historical reality and the lives of individuals with generalized historicality, in which historicality is expressed in the shell of folk fantasy, epic poetics.

\section{MAIN PART}

Historical epics occupy a special place in Uzbek folk epics. Although epic images in historical epics are involved in a real event, they depict historical generalizations in images. "When historical names are included in the epic, their owners obey the laws of epic poetics and become heroes of the epic" [1.102]. A number of researches on historical epic and its genre features have been created in Uzbek folklore [2]. Although epics on this subject are rare, they are more common in KashkadaryaSurkhandarya epics than in other regions. "Oychinor" (about Babur), "Ahmad Yassavi”, "Birth of Sahibkiran", "Birth and youth of Amir Temur", "Samarkand tarovati or Alisher Navoi”, "Epic about Qodir baxshi”, "Temur and Boyazid", "Makhtumkuli" Epics such as [3] are proof of our point. Most of these epics were written by the famous Kadyr Bakhshi Rakhimov, but we wrote them not from Kadyr Bakhshi Rakhimov, but from Kadyr Bakhshi's eldest son, a talented Bakhshi, Kakhkhor Rakhimov, and we found it necessary to think on the basis of these sources.

Kakhkhor Bakhshi, who recited the epic "Temur and Boyazid" [4], is a talented artist who learned the secrets of epic poetry from his father Qodir Rahim oglu and mastered its traditions. For this reason, the epic "Temur and Boyazid", which he sang, meets the requirements of art and traditional epic. Sedat Tamay and Botir Matyokubov, musicologists who have done special research on the musical text and notes of the epic, express the following views: "In the epic, Bakhshi praises both heroes for their country, wealth, politics, generosity and other qualities. It also describes the capital Samarkand and its climate, clear waters, orchards, a variety of fruits. The textured images in the epic, such as Amal Vazir, Shpngul momo and his son Davlat, Boyazid's daughter, Sevinch beka, son Shablikhon podsho, further enriched the development of the epic events "[5.39]. Researchers note that nineteen epic melodies were used in the epic. The epic is one of the most perfect works in terms of performance and ideology. Events in the epic "Temur and Boyazid" "yoshi oltmishni qoralagan,( over the age of sixty...) soqoliga behisht oralagan (paradise surrounded by beards), aldoqchini, firibgarni so'zi bilar yaralagan (the deceiver, the swindler, was wounded by the word), aytgan so'zi bir, ko'zi o'tkir, bo'yi o'rta, murti burda, burgut qoboq, sher yurak (one word, sharp eyes, medium height, mustache burta, eagle shell, lion heart), qoplon bilak, gavdasi kengish, mardga so'zi behish/t/, yoshi o'rta, kurak tishi bolta (tiger wrist, broad body, manly word heaven, middle age, shovel tooth ax), yomonlik qilganining umri kalta (the life of the one who does evil is short). His blow hit the enemy, and when he struck his sword, all four hands sank into the steel, Timur had a dream that day when he heard the deeds of Amir Temur from the historian Fasiq Khavari to this age, his happy moments, his occasional burns on the spot, his hard work in building a great kingdom. In his dream, Piri Bahovuddin appears, pointing to the liberation of the remaining Muslims in 
Georgia. The story begins at the same point. But the ambassadors sent were to the Georgian ruler Bukhara: After the answer, "The release of Muslims from prison is the same as Temurkhan's head," Temur's troops set out. Joining the chain of events is the fact that Sahibkiran's beloved grandson, Sultan Muhammad, fell in love with Sevinchbonu, the daughter of the Roman king Boyazid. While Timur was returning from liberating the Muslims from the Gurjis without a fight, a woman named Sangul complained to Boyazid, she begs his son to find the State, and finally Timur's escape to the presence of his two nephews, Sultan Ahmad and Qara Yusuf, Boyazid, leads to new directions in the development of the plot.

Boyazid three times rejects the ambassadors of Sahibkiran asking for the return of his traitorous navkars and even invites him to war, insulting him. This imitation is a battle between two, and Boyazid's army is defeated. With victory, but in boundless grief, Temur returns to the trail with the body of Sultan Muhammad, who was killed by the traitor Kara Yusuf. The characters of Temur, Sultan Muhammad, Boyazid, Boyazid's son Shabli, daughter Sevinchbonu, Sangul are presented in the poem in a very attractive way. In particular, the images of Temur and his beloved grandson Sultan Muhammad are depicted with passionate inspiration, sincere love. The great Sahibkiran's son Jahangir could not show his love, and the monument left to him was given to Sultan Muhammad, and his devotion and love for his grandson were boundless, and he had high hopes for him.

Temur is an old sage, a fearless warrior who has seen many battles, a great king who has built a powerful state, and most importantly, a man who cares about the future of his people, his country. He shares his grief more with Sultan
Muhammad, perfecting him as his successor. Sometimes: "Ul boshqa, to'I boshqa. Mening boyliklarim va bor toj-taxtim kuchi bilan girdi kapalak bo'layotgan farzandlar ul emas to'Idir",( It's different, it's different. This is not the children who fly with the power of my wealth and the crown I have.)- he suffers. He tells a story about Alexander and reminds his grandson that his life is short.

At the same time, the greatness of Temur is that he gathers his relatives and consults before embarking on a journey, going into battle, or embarking on a larger undertaking, listening to the suggestions of both young and old. Before the battle with Boyazid: "Who else has an opinion? Advice wedding will not be ruined, talk", Nine-year-old Ulugbek Mirzo expresses his opinion. Despite his young age, Ulugbek, who first apologized, respected his grandfather and allowed him to speak, correctly understands the good and the bad, the high and the low, the courage and the cowardice.

In the epic, the image of the Greek ruler Boyazid is not painted in black, but his bravery and strength in battle are acknowledged, proving that he is only stubborn by nature, that he makes mistakes because of this stubbornness. However, his brave son Shabli, his beautiful daughter Sevinchbonu, realizes his father's mistake.

Since Shabli is a supporter of peace, he seeks measures to prevent Temur from going to war and not to shed the blood of the people in vain. In the images of Shabli, Sevinchbonu, Sultan Muhammad, Temur, the brotherhood and friendship of the Turkic peoples are glorified. Kakhkhor Bakhshi Qodir oglu is well aware of the features of traditional epics and is able to use the peculiarities of romantic-romantic 
epics in "Temur and Boyazid". This is evident in zachin, ready-made verses, epic places.

These verses are from Sangul apa's message to Sultan Muhammad about Sevinchbonu. It is not difficult to understand how much she is glorified when he comes to the attention of young men, as she is described so highly in the language of women. If Sevinchbonu does not go out and show her beauty, the spring water will not flow, the trees will not bear ripe fruit, and when she goes out, no one will look at the moon because the face of the moon is dim in front of her face. Bakhshi uses artistic means and language resources to illuminate the image. In depicting the protagonist, we encounter a lot of adjectives, exaggerations, analogies, and animations, as in traditional epics.

Like other epics about Amir Temur, "Temur and Boyazid" serve to better understand our history, strengthen friendly ties between peoples, understand our values, increase our aesthetic and spiritual thinking.

\section{CONCLUSION}

The following conclusions can be drawn about the process of epicization of the image of Amir Temur in the context of the school of poets and epics. First, folk artists do not popularize historical reality and the image of the individual simply for performance. Perhaps he tried to embellish the image of personalities who played an important role in the worldview and psyche of people, becoming a generalized type for the epic.

Second, the events of the period of Amir Temur had a certain impact on the development of historical, social and aesthetic thinking of the people, and it serves the task of creating within the framework of the epic law.

Thirdly, the image of Amir Temur was created within the traditions of the generalized, epic school of epic poetry [6].

In general, a comparative typological study of the epics about Amir Temur, the determination of their artistic value, historical and artistic analysis is one of the urgent problems facing our folklore.

\section{REFERENCES}

1. Propp V.V. Folklore and reality. Moscow: Nauka, 1976.

2. Mirzaev T. Sarimsoqov B. Epic, its types and historical development // Epic genres of Uzbek folklore. Tashkent: Fan, 1981.

3. "Oychinor". The narrator is Qahhor Bakhshi Rakhimov. Tashkent: Ghafur Ghulam Publishing House of Literature and Art, 1985; "Ahmad Yassavi." Karshi: Nasaf, 2001; "Birth of Sahibkiran". Karshi: Nasaf, 1994; "Birth and youth of Amir Temur". Karshi: Nasaf, 1994; "Samarkand Tarovati or Alisher Navoi". Manuscript. The manuscript is in our personal archive; "A story about the Almighty. Karshi: Nasaf. 2019; "Makhtumkuli". The manuscript is in our personal archive.

4. Temur and Boyazid. Epic. Narrator Qahhor baxshi Qodir oglu. Writer and publisher A. Ergashev. Karshi: Nasaf, 2004. We take examples from this option and show the page in parentheses.

5. Epic of Temur and Boyazid. Epic-notesmusic analysis. S. Tamay., B.Matyoqubov. Ardahan, 2019.

6. Jumanazarov U. Uzbek folklore and historical reality. Tashkent: Fan, 1991. 